\title{
O PERÍODO VITORIANO: RASTROS HISTÓRICOS E LITERÁRIOS (À GUISA DE APRESENTAÇÃO)
}

\section{THE VICTORIAN AGE: HISTORICAL AND LITERARY TRACKS (AS A MEANS OF INTRODUCTION)}

Chaminés fumegantes de fábricas espalhando fumaça pelas ruas de uma Londres poluída, cidades interioranas com estradas lamacentas que paulatinamente começam a se alargar, o vapor e o calor de máquinas que dirigem o mundo para um novo paradigma de produção: a industrialização vai aos poucos levando para o esquecimento o passado de corsários dos mares, enquanto novos barcos a vapor conquistam o globo através da exploração das novas tecnologias e do trabalho das colônias. Essas são vinhetas de uma vida pulsante e real que caracteriza um período de progresso industrial, avanços nos meios de produção e muito lucro para a Inglaterra. No centro das atenções, sentada em seu solitário trono, uma jovem rainha lidera um dos mais longos e prósperos períodos da história inglesa seu nome é Vitória.

O Período Vitoriano (1837-1901) introduz transformações bruscas na sociedade inglesa e mundial. Com os meios de produção encontrando formas de fazer mais em menos tempo, as fábricas vão-se enchendo de máquinas e de novos trabalhadores, e isso inclui as baratas mãos de obra feminina e infantil. O reino prospera como a metáfora de sua época: "a todo vapor!”. Assim, o Império Britânico alcança e conquista lugares e mercados que transferem à velha Albion o epíteto "O sol nunca se põe no Império Britânico", que fora o lema, no século XVI, do imperador espanhol Filipe II. Claro que para tanto crescimento existe também um grande custo social. Surge uma nova classe social, que em inglês é referida no plural - the working classes - formada pelo operariado mal pago das grandes cidades e por outros tipos de trabalho insalubre, como o dos mineiros das minas de carvão do norte e do centro do país. O relato do padecimento dessas criaturas é amplo e se reflete nos enredos e nas temáticas de escritores do século XIX e do período eduardiano, como William Blake, Charles Dickens, Elizabeth Gaskell, Thomas Hardy, E. M. Forster, James Joyce ou D. H. Lawrence, por exemplo. São inúmeras as referências históricas e literárias sobre pessoas que perderam partes do corpo ou a própria vida nas máquinas engenhosas que produziam o mundo moderno, ou sobre como a poluição aumentou vertiginosamente provocando a morte de rios e doenças respiratórias em um ambiente que antes se orgulhava de ser a terra das fadas. No 
romance Jane Eyre a protagonista, quando criança, costumava procurar por fadas em volta dos cogumelos do jardim, até que concluiu que essas criaturas deviam ter migrado para algum lugar onde o ar era menos insalubre.

O reinado de Vitória conduz ao apogeu imperialista Inglaterra, que se encontrava em um processo de grande ebulição intelectual, política e cultural. O período é marcado por uma miríade de acontecimentos que modificaram sobremaneira a forma como os ingleses se colocavam no mundo. Na política, acompanhamos a extinção da escravidão nas colônias, a segunda revolução industrial e a Lei da Reforma, que abre o parlamento para uma visão mais democrática. O posicionamento de filósofos como Malthus e Marx são exemplos das mudanças ocorridas em terras britânicas. O período vitoriano é marcado por um embate entre a moralidade austera e os princípios religiosos de várias vertentes e as ideias do materialismo e das teorias evolucionistas de Erasmus e Charles Darwin, que começavam a ser debatidas, abrindo espaço para uma literatura riquíssima, que apresenta de forma acurada os diversos ângulos dos descompassos entre matéria e espírito que estavam na agenda de ponta da época.

$\mathrm{Na}$ capital a vida pulsava em muitas cores. A sociedade se estratificava em nichos que agrupavam a resistente aristocracia em elegante decadência, o clero, os ricos emergentes e as novas classes operárias. A Londres vitoriana era uma metrópole que nunca adormecia, um grande centro cultural no qual havia festas, bares, teatros, clubes, casas de chá e entretenimento para todas as classes sociais - desde que se tivesse dinheiro, é claro. Bancos de aposta tornaram-se comuns, especialmente em locais afastados como os cais dos portos. A prostituição proliferava junto ao luxo dos grandes salões aristocráticos ou entre o lodaçal de ruas esquecidas nos bairros mais afastados. Talvez como consequência, ou válvula de escape, pelo fato de a moralidade e a religião nunca terem sido tão fortes quanto então. Por isso o período regido pela rainha Vitória tornou-se um dos mais contraditórios da história do povo britânico, com uma literatura marcada por opostos, pelo duplo e por diversas manifestações do Gótico.

Não há dúvidas de que o período vitoriano se caracteriza por uma ebulição de ideias e de reformulações estéticas que alcançam os dias de hoje através de inúmeras reedições e adaptações de clássicos para o cinema, tv, teatro, quadrinhos e outras medias. Esta é a razão por que o presente volume da revista Organon abre espaço para uma edição sobre o período vitoriano e seus desdobramentos na contemporaneidade. Os textos selecionados exploram obras consagradas pelo cânone literário de maneiras distintas e sob diferentes vieses; e também às vezes as desconstroem, por conta de reflexões que traduzem novas formas de olhar e que forjam as reverberações contemporâneas acerca da estética vitoriana. 
Contribuíram para este volume vinte e quatro autores, provenientes das seguintes instituições: Escola Superior de Propaganda e Marketing de Porto Alegre, Universidade de Londres, Universidade do Estado do Rio de Janeiro, Universidade do Vale do Rio dos Sinos, Universidade Federal da Bahia, Universidade Federal da Paraíba, Universidade Federal de Ciências da Saúde de Porto Alegre, Universidade Federal de Santa Maria, Universidade Federal do Rio Grande do Sul e Universidade Federal Fluminense. Os escritores britânicos vitorianos contemplados com análise são o escocês Arthur Conan Doyle, os irlandeses Bram Stoker e Oscar Wilde, o galês Arthur Machen e os ingleses Charles Darwin, Charlotte Brontë, Elizabeth Gaskell, Lewis Carroll e Thomas Hardy. Temos também a estadunidense sua contemporânea Kate Chopin. Relações com autores que precedem e influenciam o período vitoriano remetem a textos anônimos do folclore gaélico, a Jane Austen e Mary Shelley. Ligações com o período subsequente, a Era Eduardiana, introduzem a estadunidense Edith Wharton e o irlandês James Joyce. Outros desdobramentos chegam a escritores mais recentes como o escocês Alasdair Gray, o inglês Blake Morrison, a dominicana Jean Rhys e os brasileiros Luiz Antonio de Assis Brasil e Luiz Ruffato, em cenários pós-apocalípticos como os do gênero Salvagepunk.

Cada autor de capítulo escolheu o seu recorte, e a juntada do material compôs um corpo de quinze artigos que contemplam a solicitação expressa na chamada para submissões, que visava compor um painel que servisse para análise tanto de textos literários produzidos durante a Era Vitoriana, como de suas repercussões em literaturas de outras nacionalidades, de outras épocas, ou em adaptações para outras medias.

A Seção Livre apresenta dois textos. O primeiro é uma entrevista inédita com o escritor inglês contemporâneo Blake Morrison, a quem agradecemos pela gentileza de disponibilizar ao entrevistador, Prof. Valter Fritsch, permissão para divulgação. A entrevista é sobre a peça We Are Three Sisters, publicada em 2011, na qual Morrison utiliza a estrutura e o enredo de As Três Irmãs, de Anton Tchekhov, para compor um panorama sobre a vida das Irmãs Brontë. O segundo texto da Seção Livre faz uma homenagem a uma das personagens mais notáveis da Era Vitoriana, Sherlock Holmes - o detetive inglês criado por seu autor escocês Conan Doyle, que tanto constrange a melhor polícia do mundo, a Scotland Yard. O texto comenta a adaptação das aventuras de Holmes para a série televisiva estadunidense Elementary, na qual o Dr. Watson, amigo de Holmes, e geralmente o narrador das histórias, é uma mulher.

$\mathrm{Na}$ seção Resenhas fomos contemplados com duas contribuições importantes. Na primeira, o tradutor e escritor José Francisco Botelho interpreta o sonho dentro do sonho 
apresentado em Alice Através do Espelho, de Lewis Carroll. Na segunda, o jornalista Israel Augusto Moraes de Castro Fritsch aproxima as percepções de mundo dos meninos narradores dos contos iniciais dos livros Dublinenses, de James Joyce, e A Cidade Dorme, de Luiz Ruffato.

Por fim, gostaríamos de agradecer à revista Organon pela confiança depositada, e a cada um dos autores por dedicarem seu tempo e trabalho valiosos para abrilhantar a presente edição, estabelecendo este diálogo profícuo que atravessa eras de história e de pensamento estético. Agradecemos também aos nossos valentes pareceristas que, comprometidos com a qualidade do material aqui publicado, fizeram uma rigorosa leitura avaliativa. Agradecemos à equipe editorial da revista Organon nas figuras da professora Maria Cristina Leandro Ferreira e da bolsista Maria Eduarda Bührer. Agradecemos por haverem acolhido nossa proposta e pela simpatia e paciência ao nos orientarem durante todo o processo.

Desejamos a todos e todas uma ótima leitura.

Valter Henrique de Castro Fritsch ${ }^{1}$ e Sandra Sirangelo Maggio ${ }^{2}$

Organizadores

\footnotetext{
${ }^{1}$ Doutor em Estudos de Literatura pela UFRGS e professor dos programas de graduação e pós-graduação em Letras da Universidade Federal do Rio Grande.

${ }^{2}$ Doutora em Estudos de Literatura pela UFRGS e professora dos programas de graduação e pós-graduação em Letras da Universidade Federal do Rio Grande do Sul.
} 